\title{
PENGARUH PEMBERIAN ANTOSIANIN DARI Ipomoea batatas L. VARIETAS UNGU KULTIVAR GUNUNG KAWI DALAM MENINGKATKAN KADAR SUPEROXIDE DISMUTASE PADA TIKUS (Rattus norvegicus) DENGAN DIET ATEROGENIK
}

\author{
Christian Julio Suhardi ${ }^{\star}$, Retty Ratnawati* ${ }^{\star \star 凶}$, Husnul Khotimah ${ }^{\star * *}$
}

\begin{abstract}
Abstrak
Penyakit jantung merupakan salah satu penyakit penyebab angka kematian tertinggi di dunia. Penyakit jantung terutama disebabkan oleh aterosklerosis yaitu kondisi plak yang menumpuk di arteri. Plak ini akan mengeras dan mempersempit pembuluh darah sehinggga tubuh akan kekurangan suplai oksigen yang dibutuhkan. Salah satu faktor yang mengawali proses aterosklerosis adalah LDL yang teroksidasi yang dipicu stres oksidatif. Stres oksidatif dapat dihambat dengan memberikan antioksidan seperti antosianin. Antosianin ini bisa didapatkan dari ubi ungu (Ipomoea batatas L) varietas ungu yang banyak terdapat di Malang. Penelitian ini dilakukan untuk mengetahui efek antosianin dari Ipomoea batatas varietas ungu kultivar Gunung Kawi pada kadar superoxide dismutase (SOD) pada kondisi aterosklerosis. Desain penelitian ini adalah eksperimental dengan membandingkan tikus dengan diet normal, tinggi lemak, dan diet tinggi lemak yang diberi antosianin lalu diukur kadar SOD dalam serum dengan metode spektrofotometri. Hasil penelitian menunjukkan bahwa pada kelompok diet normal (K-) didapatkan kadar SOD 2,6 $+0,490 \mu \mathrm{g} / \mathrm{ml}$, diet tinggi lemak $(\mathrm{K}+)$ 2,2 $+1,020 \mu \mathrm{g} / \mathrm{ml}$, perlakuan A (antosianin $5 \mathrm{mg} / \mathrm{BB} / \mathrm{hari}$ ) $3 \pm 0,632 \mu \mathrm{g} / \mathrm{ml}$, perlakuan B (antosianin $10 \mathrm{mg} / \mathrm{BB} / \mathrm{hari}$ ) $3,1 \pm 0,683 \mu \mathrm{g} / \mathrm{ml}$, dan perlakuan $\mathrm{C}$ (antosianin $20 \mathrm{mg} / \mathrm{BB} / \mathrm{hari}$ ) $3,4 \pm 0,1,170 \mathrm{Ug} / \mathrm{ml}$. Hasil uji statistik one way ANOVA diketahui bahwa tidak terdapat perbedaan kadar SOD yang signifikan antar kelompok perlakuan $(p=0,308)$. Penelitian ini menyimpulkan bahwa antosianin dari Ipomoea batatas varietas ungu kultivar Gunung Kawi tidak meningkatkan kadar SOD pada tikus Wistar (Rattus novergicus) dengan diet tinggi lemak.
\end{abstract}

Kata kunci: antioksidan, antosianin, aterosklerosis, SOD, stres oksidatif

\section{EFFECT OF ANTHOCYANIN FROM PURPLE SWEET POTATO (Ipomoea batatas L.) KAWI MOUNTAIN CULTIVARTO INCREASE SOD SERUM IN WISTAR RAT (Rattus norvegicus) WITH ATHEROGENIC DIET}

\begin{abstract}
Heart disease is one of the diseases in the world that leading to death. It is mainly caused by atherosclerosis, a condition that plaque will accumulate in an artery which hardens and narrow the blood vessels. This causes the supply oxygen to the body, will be diminished. One of the factors that initiate the process of atherosclerosis is the oxidized LDL triggered by oxidative stress. Oxidative stress can be reduced by giving antioxidant supplements such as anthocyanin that can scavenge free radicals. Anthocyanin can be obtained from purple sweet-potato (Ipomœa batatas L.) that are planted widely in Malang. This research aimed was to know the effect of anthocyanin from purple Ipomea batatas $L$. to increase SOD level in atherosclerotic condition. The research was used experimental design by comparing the group with a normal diet, high fat diet, and high fat diet with anthocyanin supplementation then measuring SOD level by spectrophotometry. The result showed the SOD level in normal diet group (K-) was $2.6+0.490 \mu \mathrm{g} / \mathrm{ml}$, high fat diet group $(\mathrm{K}+)$ was $2.2 \pm 1.020 \mu \mathrm{g} / \mathrm{ml}$, treatment A group (anthocyanin $5 \mathrm{mg} / \mathrm{BW} /$ day) was $3 \pm 0.632 \mathrm{Ug} / \mathrm{ml}$, treatment $B$ group (anthocyanin $10 \mathrm{mg} / \mathrm{BW} /$ day) was $3.1 \pm 0.683 \mu \mathrm{g} / \mathrm{ml}$, and treatment $C$ group (anthocyanin $20 \mathrm{mg} / \mathrm{BW} / \mathrm{day}$ ) was $3.4 \pm 1.170 \mu \mathrm{g} / \mathrm{ml}$. Based on one way ANOVA test showed there was no significant difference between SOD serum level in each groups $(p=0.308)$. It can be concluded that anthocyanin from purple Ipomea batatas L. can not increase SOD level in Wistar rat (Rattus novergicus) with atherogenic diet.
\end{abstract}

Keywords: atherosclerosis, anthocyanin, antioxidant, SOD, stress oxidative

* Program Studi Pendidikan Dokter, FKUB.

** Lab Faal, FKUB.

${ }^{* * *}$ Lab Farmakologi, FKUB

ĐE-mail: rettyrst@yahoo.co.id 


\section{Pendahuluan}

Penyakit jantung merupakan salah satu penyakit penyebab kematian tertinggi di dunia. Hal ini ditunjukkan dari 48\% kematian di dunia yang disebabkan oleh penyakit tidak menular disebabkan oleh penyakit kardiovaskuler. Pada tahun 2008 diketahui 17,3 juta orang meninggal karena penyakit kardiovaskular, 7,3 juta karena serangan jantung dan 6,2 juta karena stroke. ${ }^{1}$ Sementara di Indonesia angka kematian yang disebabkan oleh penyakit jantung coroner (PJK) mencapai 26\%. Hasil survei kesehatan rumah tangga nasional (SKRTN), menunjukkan bahwa dalam 10 tahun terakhir angka tersebut cenderung mengalami peningkatan. WHO juga memperkirakan bahwa pada tahun 2030 sekitar 23,6 juta orang akan meninggal karena penyakit kardiovaskular. Riset Kesehatan Dasar (Riskesdas) 2007, menunjukkan bahwa prevalensi penyakit jantung secara nasional adalah $7,2 \%$, dan penyakit jantung iskemik mempunyai proporsi sebesar $5,1 \%$, dan stroke $15,4 \%$ dari seluruh penyakit penyebab kematian di Indonesia. ${ }^{2}$

Penyakit jantung ini terutama disebabkan olehaterosklerosisyaitu suatu kondisi dimana plakmenumpuk di arteri yang seharusnya membawa darah yang kaya akan oksigen ke seluruh tubuh kita . Plak ini terdiri dari lemak, kolesterol, kalsium, dan banyak bahan lain yang terdapat di darah. Plak ini akan mengeras dan mempersempit pembuluh darah sehinggga tubuh akan kekurangan suplai oksigen yang dibutuhkan, seperti jantung kita. Hal ini akan mengakibatkan berbagai penyakit seperti serangan jantung dan stroke yang dapat berujung pada kematian. ${ }^{3}$

Sampai saat ini penyebab pasti dari aterosklerosis belum diketahui, tetapi penelitian sebelumnya mengindikasikan bahwa aterosklerosis dimulai saat bagian dalam arteri dirusak oleh faktor-faktor tertentu. Saat terjadi kerusakan, tubuh memulai proses penyembuhan luka, salah satunya dengan membentuk plak di arteri yang terluka. Pembentukan plak ini dapat terjadi sejak masa kanak-kanak. Dan ada beberapa kondisi, kebiasaan yang dapat meningkatkan resiko aterosklerosis, yaitu kadar kolesterol darah yang tinggi,tekanan darah yang tinggi, merokok,resistensi insulin, diabetes, obesitas, kurangnya aktivitas fisik, penuaan (resiko bertambah seiring dengan bertambahnya usia), serta riwayat keluarga tentang penyakit jantung pada usia muda. ${ }^{4}$

Salah satu faktor yang mengawali proses aterosklerosis adalah LDL yang teroksidasi. Hal ini dapat disebabkan oleh stres oksidatif yaitu suatu kondisi ketidakseimbangan antara produksi ROS (oksidan) dan aktifitas dari antioksidan sebagai pertahanan. Peran radikal bebas seperti superoxide, peroksidase tubuh, seharusnya diimbangi oleh faktor enzim antioksidan seperti superoxide dismutase (SOD), glutathione reduktase, katalase ataupun vitamin $E$, vitamin $C$ ataupun antioksidan lainnya. ${ }^{5}$

Stres oksidatif ini dapat dicegah dengan beberapa cara, diantaranya dengan pemberian antioksidan yang diekstrak dari tumbuhan di daerah tropis. Salah satu bahan bioaktif yang dapat digunakan sebagai antioksidan untuk mencegah aterosklerosis adalah antosianin. Antosianin dapat menghambat proses oksidasi dari low density lipoprotein (LDL) dan melindungi integritas sel endotel yang melapisi dinding pembuluh darah. Namun peneliti lain menyebutkan bahwa pemberian suplemen antioksidan tunggal dan antioksidan kombinasi tidak menghasilkan hasil yang konsisten dalam mengurangi angka kematian akibat penyakit kardiovaskuler. ${ }^{6}$ Oleh karena itu, penelitian mengenai keefektifan dari antioksidan perlu ditelusuri lebih lanjut.

Salah satu tumbuhan di Indonesia yang mengandung antioksidan cukup banyak adalah ubi jalar ungu (Ipomea batatas L.). 
Ubi ini banyak dikembangkan di kota Malang dan memiliki harga yang murah. Di daerah pegunungan Kawi, Kabupaten Malang banyak dijumpai varietas ubi ungu yang merupakan komoditas andalan daerah tersebut. Ubi jalar ungu banyak dijual dengan harga murah di kota Malang. Antosianin merupakan zat warna dari tumbuhan yang memiliki warna antara merah sampai ungu. Dalam $100 \mathrm{~g}$ ubi ungu, terdapat $561,11 \mathrm{mg}$ antosianin. ${ }^{7}$ Efek antosianin dari ubi ungu sebagai antiaterosklerosis telah banyak diteliti. ${ }^{8}$ Penelitian ini ingin mengetahui pengaruh antosianin ubi jalar sebagai antiaterosklerosis melalui peningkatan kadar SOD serum.

\section{Bahan dan metode}

\section{Desain Penelitian}

Penelitian ini merupakan penelitian eksperimental post test only control group design pada tikus Wistar (Rattus norvegicus) jantan yang diberi diet tinggi lemak. Setiap hari tikus diberi makan berupa diet normal.

\section{Lokasi dan Waktu Penelitian}

Pemeliharaan hewan coba dan pengukuran kadar SOD serum dilaksanakan di Laboratorium Fisiologi, Fakultas Kedokteran Universitas Brawijaya pada bulan Juni sampai dengan September 2013.

\section{Sampel Penelitian}

Sampel penelitian yang digunakan adalah 25 ekor tikus galur Wistar (Rattus norvegicus). Sampel dipilih secara acak dan kemudian dibagi ke dalam lima kelompok yang masingmasing terdiri dari 5 hewan coba, yaitu kelompok kontrol negatif (diet normal), kontrol positif (diet tinggi lemak), perlakuan A (diet tinggi lemak + antosianin $5 \mathrm{mg} / \mathrm{kgBB} / \mathrm{hari}$ ), perlakuan $B$ (diet tinggi lemak + antosianin 10 $\mathrm{mg} / \mathrm{kgBB} /$ hari), dan perlakuan $\mathrm{C}$ (diet tinggi lemak + antosianin $20 \mathrm{mg} / \mathrm{kgBB} / \mathrm{hari})$.

\section{Persiapan Hewan Coba}

Tikus sebelumnya diaklimatisasi selama 10 hari dengan diberi diet normal dan diet tinggi lemak sesuai kelompok perlakuan. Diet diberikan setiap hari sebanyak 30 g/ekor tikus/hari. Sisa pakan kemudian diambil dan ditimbang setelah 24 jam. Hasilnya kemudian dihitung sebagai rata-rata asupan pakan harian tikus/ kelompok/ hari.

\section{Karakterisasi Antosianin Ipomoea batatas L. Varietas Ungu}

Antosianin diperoleh dari proses ekstraksi, isolasi, pemurnian, dan karakterisasi di Laboratorium Kimia FMIPA ITB. Ekstraksi dilakukan secara maserasi dengan merendam sampel dalam pelarut etanol- $\mathrm{HCl} \quad 0,01 \%$ selama 14 jam pada suhu ruang. Pemisahan antosianin dari ekstrak sampel dilakukan dengan kromatografi kolom flash termodifikasi dengan poliamida CC-6 sebagai fasa diam dan sebagai fasa gerak ialah air dan etanol. Untuk mengetahui jumlah senyawa antosianin dalam sampel dilakukan high performance liquid chromatography (HPLC). HPLC menggunakan fasa diam $\mathrm{C}_{18}$ dan fasa gerak gradien pelarut air : asam format (95:5) dan asetonitril : asam format (95:5). Selanjutnya antosianin dihidrolisis dengan $\mathrm{HCl}$ untuk menghasilkan antosianidin. Untuk mengetahui sifat optik antosianin hasil pemisahan dilakukan pengukuran spektrum UV-Vis dan untuk mengetahui struktur antosianidin dilakukan pengukuran spektrum infra merah, spektrofotometer massa dan resonansi magnetik inti. Bioaktivitas antosianin hasil pemisahan diukur dengan uji antioksidan menggunakan metode 1,1-difenil-2pikrilhidrazil. ${ }^{9}$

\section{Bahan Diet yang Diberikan pada Tikus}

Bahan untuk diet normal terdiri dari tepung jagung, gula pasir, soybean oil, gelatin, kasein, CMC, vitamin, mineral, air, pewarna merah, dan essens keju.Bahan untuk diet tinggi lemak terdiri dari tepung jagung, gula pasir, corvet, margarin, pig oil, soybean oil, gelatin, kasein, CMC, vitamin, mineral, air, pewarna hijau, asam kolat, kuning telur, dan essens keju. ${ }^{10}$ 


\section{Pembedahan}

Pada akhir hari ke-96 dilakukan pembedahan pada tikus. Sebelumnya tikus dieutanasia menggunakan ketamine. Setelah itu tikus dibedah, lalu diambil darahnya dari jantung.

\section{Pengukuran Kadar SOD}

Serum darah yang didapat dari masingmasing tikus kemudian diukur kadar SOD tikus dengan metode spektrofotometri.

\section{Analisis Data}

Hasil penghitungan kadar SOD serum tikus dianalisis secara statistik menggunakan uji one way ANOVA dengan tingkat kepercayaan $95 \%(\alpha=0,05)$.

\section{Hasil}

Penghitungan kadar SOD serum dilakukan menggunakan spektrofotometri. Pada penelitian ini didapatkan data hasil penelitian pada masing-masing kelompok perlakuan seperti pada Tabel 1 .

Tabel 1. Kadar SOD serum pada kelompok tikus kontrol dan perlakuan

\begin{tabular}{lc}
\hline Kelompok Perlakuan & $\begin{array}{l}\text { Kadar } \\
(\mu \mathrm{g} / \mathrm{ml})\end{array}$ \\
\hline Kontrol Negatif $(\mathrm{K}-)$ & $2,6 \pm 0,490$ \\
Kontrol Positif $(\mathrm{K}+)$ & $2,2 \pm 1,020$ \\
Perlakuan A & $3,0 \pm 0,632$ \\
Perlakuan B & $3,1 \pm 0,683$ \\
Perlakuan C & $3,4 \pm 1,170$ \\
\hline
\end{tabular}

Keterangan: K- (diet normal tanpa pemberian antosianin), $\mathrm{K}+$ (diet tinggi lemak tanpa pemberian antosianin), Perlakuan A (diet tinggi lemak + antosianin $5 \mathrm{mg} / \mathrm{hari}$ ), Perlakuan $\mathrm{B}$ (diet tinggi lemak + antosianin $10 \mathrm{mg} / \mathrm{hari}$ ), Perlakuan C (diet tinggi lemak + antosianin $20 \mathrm{mg} / \mathrm{hari}$ ).
Hasil penelitian rata-rata kadar SOD serum pada masing-masing kelompok perlakuan dengan diet normal dan tinggi lemak dengan atau tanpa pemberian antosianin disajikan pada Gambar 1.

\section{Uji One Way ANOVA}

Dari hasil uji normalitas didapatkan nilai signifikansi untuk semua kelompok $>0,05$, sedangkan dari hasil uji homogentias didapatkan nilai signifikansi sebesar 0,396. Nilai tersebut menunjukkan terpenuhinya syarat untuk dilakukan uji one-way ANOVA. Hasil analisis one way ANOVA (uji Tuckey) menunjukkan nilai signifikansi sebesar 0,308. Hal ini berarti perbedaan kadar SOD serum yang terdapat pada masing-masing kelompok perlakuan adalah tidak bermakna. Dengan demikian hipotesis dari penelitian ini (H1) ditolak dan $\mathrm{HO}$ yang diterima, yaitu antosianin dari Ipomoea batatas $L$. varietas ungu tidak dapat secara signifikan meningkatkan kadar superoxide desmutase (SOD) darah tikus (Rattus norvegicus) yang diberi diet aterogenik. 


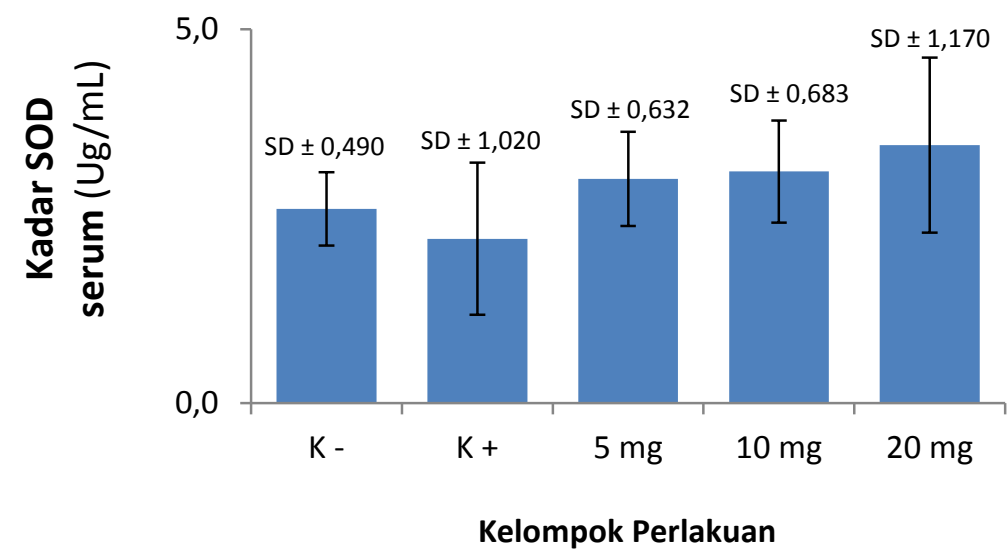

Gambar 1. Perbandingan rata-rata kadar SOD serum pada kelompok kontrol dan perlakuan Keterangan: K- (diet normal tanpa pemberian antosianin), K+ (diet tinggi lemak tanpa pemberian antosianin) Perlakuan A (diet tinggi lemak + antosianin $5 \mathrm{mg} / \mathrm{hari}$ ), Perlakuan B (diet tinggi lemak + antosianin $10 \mathrm{mg} / \mathrm{hari}$ ), Perlakuan C (diet tinggi lemak + antosianin $20 \mathrm{mg} / \mathrm{hari}$ ).

\section{Pembahasan}

Pada studi ini dilakukan pengamatan terhadap pengaruh pemberian antosianin dari Ipomoea batatas $L$. varietas ungu dalam upaya meningkatkan kadar SOD darah pada tikus (Rattus norvegicus) yang diberi diet tinggi lemak. Tikus model aterosklerosis dibuat dengan melakukan pemberian pakan tinggi lemak. Setelah 3 bulan pemberian diet tinggi lemak, terlihat adanya pembentukan sel busa yang merupakan pertanda bahwa proses aterosklerosis.

Paparan dari radikal bebas dari berbagai sumber dapat menyebabkan berbagai respon yang menyebabkan kerusakan. Tetapi tubuh memiliki mekanisme defensif seperti mekanisme preventif, mekanisme perbaikan, mekanisme fisik, dan mekanisme antioksidan. Antioksidan adalah molekul yang meperlambat ataupun menghambat proses oksidasi dari molekul lain. ${ }^{12}$ Mekanisme antioksidan meliputi enzimatik seperti superoxide dismutase (SOD), glutathione peroxidase (GPx), catalase (CAT) dan non enzymatik seperti vitamin $C$, vitamin $E$, glutathione (GSH), karotenoid, flavonoid, dan lain sebagainya. Dalam kondisi normal selalu ada keseimbangan antara antioksidan dan radikal bebas..$^{13}$

Stres oksidatif dapat dicegah dengan beberapa cara, di antaranya dengan pemberian antioksidan tambahan yang berasal dari tumbuhan daerah tropis. Salah satu bahan bioaktif yang dapat digunakan sebagai antioksidan untuk mencegah aterosklerosis adalah antosianin. ${ }^{11}$ Pemberian zat antioksidan dari tumbuhan telah banyak dilaporkan turut mencegah ataupun memperlambat proses penyakit kronis atau degeneratif seperti penyakit jantung. ${ }^{14}$ Salah satu zat antioksidan ini adalah antosianin yang banyak terdapat di dalam ubi ungu. ${ }^{15}$ Pada penelitian sebelumnya menyebutkan bahwa pemberian antioksidan pada tikus dengan beban latihan yang maksimal didapatkan penurunan MDA yang merupakan penanda stres oksidatif secara signifikan. ${ }^{16}$ Diharapkan dengan pemberian antioksidan ini akan mengurangi stress oksidatif yang terjadi sehingga dapat mengurangi NO yang berubah menjadi ONOO- Ketersediaan NO di dalam endotel 
akan merangsang enzim p38MAPkinase yang akan meningkatkan proses produksi SOD melalui jalur CGMP. ${ }^{17}$

Pada penelitian ini juga dilakukan penghitungan sel busa yang menunjukkan perbedaan yang bermakna pada tiap kelompok penelitian. Hal ini menunjukkan bahwa kadar ecSOD yang didapatkan tidak berbeda secara bermakna disebabkan proses yang terjadi di dalam tiap kelompok tikus berbeda. Pada kelompok yang diberi antosianin (perlakuan $\mathrm{A}$, perlakuan $\mathrm{B}$, dan perlakuan $\mathrm{C}$ ), didapatkan kadar ecSOD meningkat dengan jumlah sel busa yang menurun. Sementara pada kelompok kontrol positif, diketahui bahwa kadar ecSOD berbeda nyata dibandingkan dengan kelompok kontrol negatif yang memiliki jumlah sel busa yang tinggi. Jadi, dapat disimpulkan bahwa kadar ecSOD yang meningkat pada tikus dengan pemberian antosianin dapat mengimbangi radikal bebas, sehingga dapat menjaga fungsi endotel dengan baik. Sementara pada tikus kontrol positif telah terjadi disfungsi endotel yang mengakibatkan tubuh tidak dapat memproduksi antioksidan yang dapat mengimbangi jumlah radikal bebas dalam tubuh. Penelitian ini menunjukkan bahwa tikus yang diberi diet aterogenik tanpa pemberian antosianin mengalami penurunan kadar SOD. Hal ini diduga karena banyaknya jumlah radikal bebas yang akan mengubah NO menjadi ONOO- yang akan menurunkan bioavaibilitas NO, dan menurunkan kecepatan dan proses produksi SOD. Pada kelompok yang diberikan antosianin mengalami peningkatan kadar SOD karena antosianin yang diberikan akan berikatan dengan radikal bebas sehingga jumlah radikal bebas yang berikatan dengan NO akan menurun dan bioavaibilitas NO tetap terjaga yang akan meningkat pembentukannya oleh aktivasi nrf-2. Namun, hasil penelitian ini tidak signifikan yang ditunjukkan dengan nilai $p=0,308(p>$ 0,005).
SOD merupakan enzim antioksidan yang utama yang menetralisir superoksida, enzim ini bekerja dengan cara mengkatalisa perubahan superoksida menjadi hydrogen peroksida. Enzim ini dalam proses produksinya dipicu oleh kadar endhotelial NO synthetase (eNOs) yang merupakan regulator positif dari mRNA yang menghasilkan SOD terutama ecSOD. Pada proses aterosklerosis terjadi penurunan kadar eNOs, diharapkan kadar SOD yang dihasilkan akan ikut menurun, dan sebaliknya. ${ }^{18}$

Pada saat tubuh mengalami stress oksidatif, tubuh akan meresponnya dengan menghasilkan antioksidan juga untuk melindungi tubuh seperti SOD, katalase, gluthathion peroksidase. Namun jika stres oksidatif terus berlanjut maka dapat terjadi kerusakan sehingga tubuh tidak mampu menghasilkan antioksidan untuk mengimbanginya. Pada penelitian Fukai (2011) menyebutkan kadar ecSOD pada tikus dengan diet tinggi lemak akan menurun setelah 1 bulan. Hal ini menunjukkan bahwa fungsi endotel yang menurun oleh karena ROS, akan tetapi setelah 3 bulan kadar ecSOD akan mendekati normal. Proses ecSOD yang mendekati normal tersebut belum dapat dijelaskan. Sehingga tingginya kadar SOD pada tikus kontrol positif dalam penelitian ini dapat disebabkan oleh hal tersebut, sehingga hasil yang didapatkan tidak menunjukkan perbedaan bermakna.

Kadar ecSOD terbagi menjadi 2 yaitu ecSOD yang menempel di jaringan endotel yang berjumlah $90-99 \%$, sedangkan sisanya berada di sirkulasi. Hal ini dapat menimbulkan hasil yang sangat bervariasi di dalam penelitian ecSOD serum yang mengakibatkan tingginya standar deviasi oleh karena rentang ketersediaan ecSOD dalam serum antara $1 \%$ sampai $10 \%{ }^{19}$, selain juga dapat mengakibatkan hasil yang didapatkan menjadi tidak berbeda secara nyata. 


\section{Kesimpulan}

Antosianin dari Ipomoea batatas varietas ungu kultivar Gunung Kawi tidak meningkatkan kadar SOD pada tikus Wistar (Rattus novergicus) dengan diet tinggi lemak secara signifikan.

\section{Daftar Pustaka}

1. (WHO) World Health Organization. Global Atlas on Cardiovascular Disease Prevention and Control. Geneva. 2011. P2-6.

2. Riskesdas. Laporan Nasional 2007. Badan Penelitian dan Pengembangan Kesehatan Departemen Kesehatan Republik Indonesia.2007. HIm 114-115.

3. NHLBI. What is Atherosclerosis? (Online) 2009. https://www.nhlbi.nih.gov/health/healthtopics/topics/atherosclerosis/. Diakses 5 desember 2012. jam 16:00

4. McGill HC Jr, McMahan CA, Gidding SS.Preventing Heart Disease in the 21st Century : Implications of the Pathobiological Determinants of Atherosclerosis in Youth (PDAY) Study. Circulation. 2008;117:1216-1227.

5. Sargowo D. Peran Radikal Bebas dalam Patogenesa Aterosklerosis. Jurnal Kardiologi Indonesia. 1997; 3(22):168182.

6. Katsiki N, Manes C. Is There a Role for Supplemented Antioxidants in Prevention of Atherosclerosis?.Clinical Nutrition. 2009.3-9

7. Trisnanto R. Ekstraksi Antosianin dari Ubi Jalar Ungu (Ipomoea batatas L. Klon Msu 03028-10) dan Aplikasinya sebagai Pewarna Alami pada Sirup. (Online).

2011.http://elibrary.ub.ac.id/handle/1234 56789/30598.

8. Frolov A, Hui DY. The Modern Art of Atherosclerosis: A Picture of Colorful Plants, Cholesterol, and Inflammation. Arteriosclerosis, Thrombosis, and
Vascular Biology Journal. 2007; 27:45045.

9. Jadmiko S. Ekstraksi, Isolasi, Pemurnian, dan Karakterisasi Antosianin dari Ubi Jalar Ungu (Ipomoea batatas L.). Thesis. Tidak diterbitkan.Bandung: Institut Teknologi Bandung.2013.

10. Handayani D. Prevention and Treatment of High Fat Diet-Induced Obesity by Dietary Intake of Shiitake and Oat. Heath and Behavioural Faculty. Wollongong: University of Wollongong.2012.

11. Zhu F, Zhong CY,Yang $Z$, Ke J, dan Corke $H$. Anthocyanins, Hydroxycinnamic Acid Derivatives, and Antioxidant Activity in Roots of Different Chinese Purple-Fleshed Sweetpotato Genotypes. J Agric Food Chem.2010; 58(13):7588-7596.

12. Mohammad M, Dar A, Soomro MT,Tariq $M$, Latif $M$. Antioxidants/antioxidative agents and superoxide: An electrochemical monitoring device. International Journal of Genetics and Molecular Biology. 2009; 1(6):105-114.

13. Valko M, Leibfritz D, Moncol J, Cronin MTD, Mazur M, Telser J. Free Radicals and Antioxidants in Normal Physiological Functions and Human Disease. Int J Biochem Cell Biol. 2007; 39(1): 44-84.

14. Pham-Huy LA, Hua He, Pham-Huy C. Free Radicals, Antioxidants in Disease and Health. Int J Biomed Sci. 2008; 4(2):89-96.

15. Zhu F, Zhong Cai Y,Yang Z., Ke J, Corke H. Anthocyanins, Hydroxycinnamic Acid Derivatives, and Antioxidant Activity in Roots of Different Chinese Purple-Fleshed Sweetpotato Genotypes. J Agric Food Chem. 2010; 58(3):7588-7596.

16. Jawi IM, Suprapta DN, Arcana I N, Indrayani AW, Subawa AAN. Efek Antioksidan Ekstrak Air Umbi Ubi Jalar 
Ungu (Ipomoea batatas L) terhadap Darah dan Berbagai Organ pada Mencit yang Diberikan Beban Aktivitas Fisik Maksimal. JumalFarmakologi. 2010.

17. Fukai Tdan Fukai MU. Superoxide Dismutases: Role in Redox Signaling,Vascular Function, and Diseases. Antioxidants \& Redox Signaling. 2011; 15(6):1583-1606.
18. Fukai T. Extracellular SOD and Aged Blood Vessels. Am J Physiol Heart Circ Physiol. 2009; 297:10-12.

19. Marklund SL. Expression Of Extracellular Superoxide Dismutase by Human Cell Lines. Biochem J. 1990; 266:213-219. 